TO:

FROF:

SURJTCT:
Phil R. Hollsworth, Commiseionex offunes

H. Jasper, Associate lining Bnglneer

Fiele trip to Tuxedni Bay (ex-Snug Harbor), Cook Inlet, by $Y$. $:$. Jasper and Thos. Thomes, assistant, to investigate reported magnecite occurrence.

Hention is mada in U. S. G. 3. 722-D, 1921

hoppit of maknetite occurrerce at westerly end of aoeninsula. extending out and into Tuxedn1 Pay. A map in the former bulletin (702-D) marks the aporoximate location; in oujJetin 7 so comment is made that "deposit was not visited but was described to bim by the owner, Roy A. Trachsel".

The reportei occurrence is more closely describea by Long1 tude $152048^{\circ}$ and Latituge North $60^{\circ} 141$; it is probably located withy iron stained area on the eouth siopes in the central or Basterly helî of the pentnsuly. It apoarently (reoorted7y) cuts the roloanje rocks at a point not far from the erand to intrusive contact.

May 30: Left Werrill pield et $7: 17$ A. $\because$. with Thos. Thomas in chartexed Ploer Cuo with pllot-omer "Pat" Kelly, landing on tideflats on north slde of peningula et $8: 45 \mathrm{~A}$. i... Arrangenerts made for pllot to return at 4;30-5:00 P. H.

"sth mop showing the roported magnotite occur rence at westerly end of the penlneula (PLAlla 2, USGS Bul. 722D) sncl on 1 ts south side, the oase and lower north and west slopes to the point shown on map on south side was exanjned Ior. ngenetite "ilost", and bedrock exposures for minerelization. No masnetite was found. In courge of this traverge, and the minerallration observed was linited to disseminoted pyrite in both light end dark colorea voJ, canics, as well as in argillite and. cuertaite "remnants" at or near grenitic "tongues" or dikes.

The distance traversed from point of plane landing on the tide-filats ras approximately 3 miles. On reaching the rocky point on sbuth side and at westerly end of the ridee about 1:30 P. I. , the incoming tide prevented examination of the hichly oxidized and very steep rocky slopes a hali mile to l. or 2 miles further east, and return was inade to the starting: nolnt by $4 \mathrm{P}$. M. to contact the plane.

In section examined that area can be elininated for the present ao far as having any besring on the reported. magnetite occurrence is concerned. Further juvertigation of

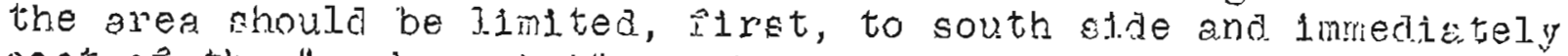
east os the "rocry point" reeched, ara second, to eastern half 
of the pentneula on north side of riege.

It is regramended that further investigation of the area be services by boat irom Ninilchle, Kasilof, or Kenai, with a base established at east end of the peninsula cue to quick chenge of weather in the district, and also due to rocky beach itine on the south (Tuxedni Bay) side of the rldge. Those conditions coupled with the strong tide create a, "hazard" for vontoon eculpped planes along that section of the beach.

Due to an afternoon change in the weother, pllot was deliyed in returning, landing on beach for several

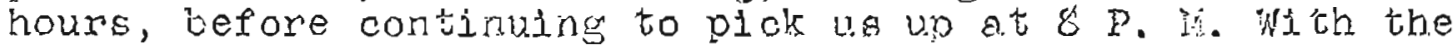
rain softentng the "mud flats" plane was unable to take-off with three, relaytng us in two tripe to beash figherman'a cove near mouth of Grecian River.

of liay 30 th, 1953.

Returned to Anchorge at $20: 30$ P. M. night prints recelved.

Pictures of area will be forwarded when

Respectruliy submitted,

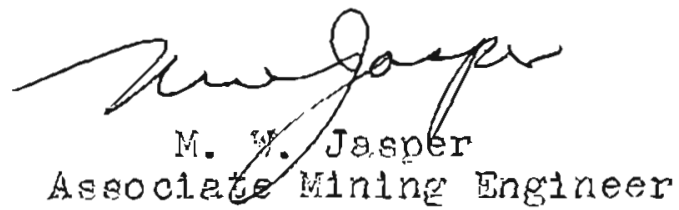




\section{June 16,2953}

ITIMTRARY RPPCRT

TO:

Ph11. R. Holdeworth, Comns sioner op lines, Territory of Alaska, Jineau, Alaska.

FISOI:

1. I. Jasper, desocicte Minine ingineer.

QUบJ:3:

Macnetf te investigetion, Tuxecht Bay (Snup Haribor) area, Cook Inlet, on Alarke Peninsula, by i. it. Jasper end A. H. Unton, Consulting luning ngineer of Seattine, in.

This repont suoplements that subititer June s, 1.953 , which covered the norit? site and west end of the peninsula, wich 1.3tter is on north sile of Tuxerni Bay.

Pred H. Hortet of the U. S. Geologlcrl Survey, on mep lraluded in bulletin 7?2-D, 192l, merke location of the report-

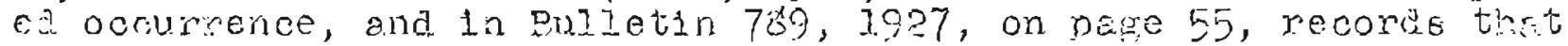
"beposit res not visited but, was descrlied to him by the orner, Poy A. Trachoel."

The reportad occurrence is mone closely äsor.tod,

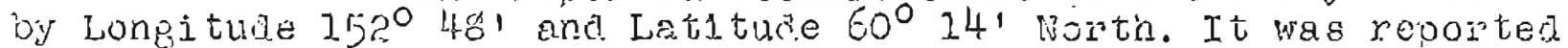
as culting the volcanics at noint not far iron an sranitic intrusI ve consect, et point at rest end and on south side of the ringe.

The Invertigetiun of June 12th, 1053, which coverad time south sile or the peninsular ridpe, failed to locate vacurrance of a magetate jepoelt which could be considereg of possible economic jimportance.

June llth: Fullowing arrengements nade by telephone with Car? KJbbey at Homer for charter of hj.s 3 f foot oas porered flshing boat for the trip to Tureand Bey, we left Anchorge by orfvate cer, arriving at Homen et 7 P. W. Departure from Horner was mate at 7.1 P. M. With Mr. Kibbey in his boat the Ko, leen, ac-

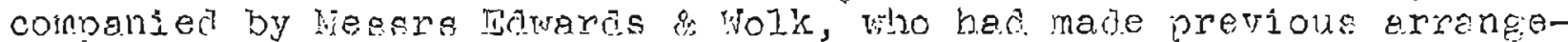
mente for the trity to dig clams ofi-shore from Poll.y Creek, 3 or 10 miles northerst of Tuxedni. Bay.

June 1?tin: Arrived and anchored off polly Creet at $6 \mathrm{~A}$. , fer hours wefore low tile, remantig for ilve hours

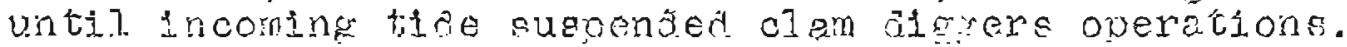

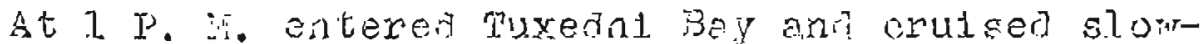
ly near ane alone south side of ridge for la houre. The steep and orecioltioue gouth slooes ath bejrock exposures evirent for greater bert or the area, rere exames closely with fjeld ejagses ror the nonmal.y "black" magnetfte outcrors but none were observel, except a very amal. (narrow) and short, Irregular vutcroo in face of a low blufí cistng rron shoreline a huidrea varis east of most westerly 
'puxeans. Bey

itagnetite Invertigetion

June $1 ?, 1953$

point on south side of the rldge(approxtnate polnt shown by foppit).

Going ashore at 2:30 P. H. With irs. Upton; the telus and bedrock outcrons were closely exanined for length (hi to ? milee)

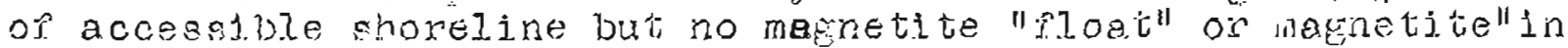
plecell we found. This section - extending from point short disance (avout 100 yards) eget of probable point refere? to by Mr. Horfit at west end of south shoreline, thence easterly - is comosed of a series of varioue colorer volcanico and severel felciapar porphyry alkes. The volcanics are in contact with a granitio intrugive at esst end of this lis to ? mile section.

Minerolization 1 a ljmited to diseminated byrite, some marcast te, and oligbtily more abundent pyrrbotite as encill. veinleta anc disserninations in the volconics. What appexys to be a frirly heavy "gossen" on large talus ond cliff faces is actually liniteri to a thlin shell of limonite, deriverl largely from oxidation of the pyrnhotite. There is no appreclabie jncrease of pyritization as the erendtio intrustve is aprosched.

Further investigation of the area for magnetite occurrence is te not justified. The snall 1 solated occurrence is not of econonic inportande. To be of interest in this area, a depoedt woind have to bentain a minlmum of one ralliton tons of e falrly hich grade.

Cost of exploitine derosit in that ristrict would renuire a costly docking installation for loading "deep sea" ships, as the low tide "flate" extend for 750 to 1000 feet oft-ghore, and it is $\&$ duestion as to thether the channel at low tico woula heve enough water for freighters lin the inmediate vicluity.

Renorts of a recent "epidemic" of claim staking in the area was not conflrmed; no signs of recent or old ataking was observed.

Fieturn to the boat was made at $5: 30$ P. H. June lath, and anchurge for the raght was made at north end of chish Is.

June 3.3th: The boat returner to the clam beds off

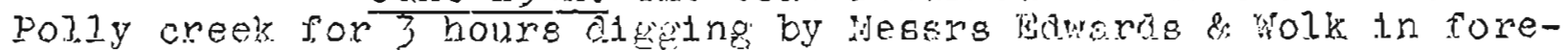
noon. Left th18 anchorage at 12:30 P. M. and returned, to Homer at 9 P. M. Cost of the boat charter wes 100.00 , wht.ch wes pata by Mr. Uoton.

At $9: 30$ p. $\%$. Jeft Homer by private cer on return trip to snchorage, arriving at latter point at 4:30 A. 1.. June 74.

Uaps 1 and 2 of the area are appended. Snapshots N.1.1 be forwarded when recelved for attachlng to this report.

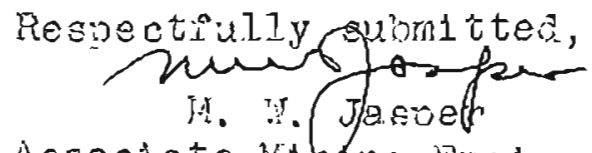




\section{$+7$}
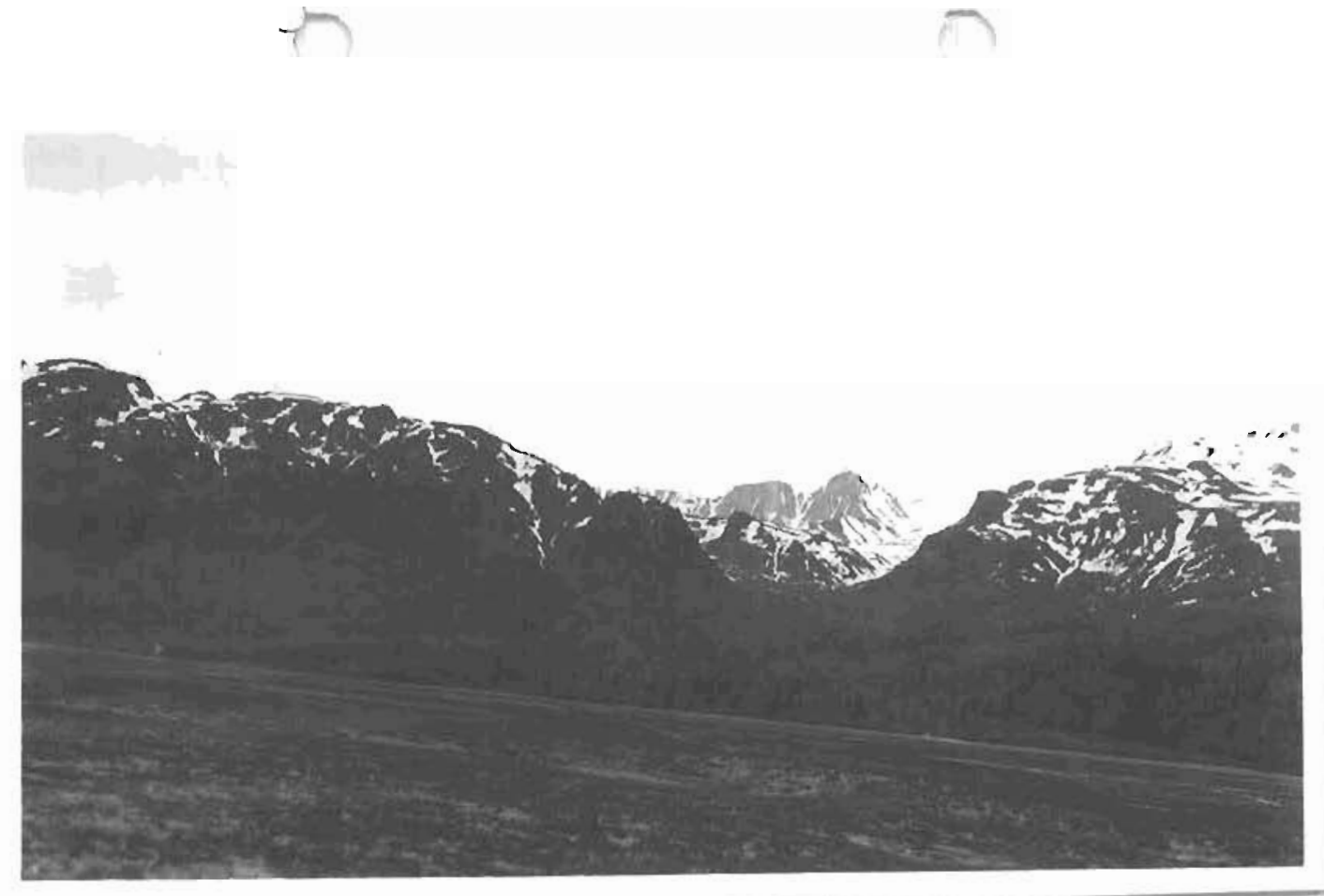

Looking north from west end of ridge across tide-flats. Tuxedn1 Bay, Alagka. Peninsula, magnetite investigation. May 30, 1953

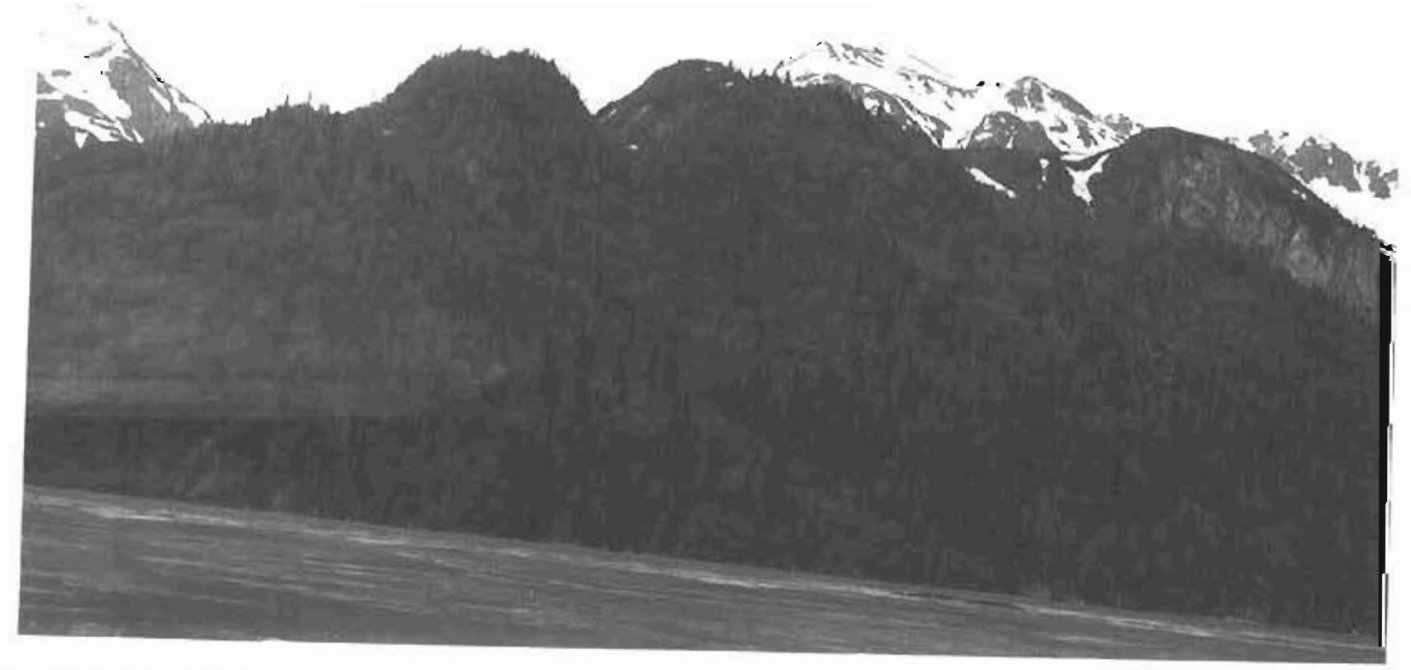

Looking north from northwest end of ridge across eastwest tide-flate on north slde of ridge. Tuxedni Bay magnetite investigation. May 30, 1953 
Looking southeasterly from northwest end of ridge. Tuxedni Bay, Alaska Peninsula, magnetite investigation.

$$
\text { May 30, } 1953
$$

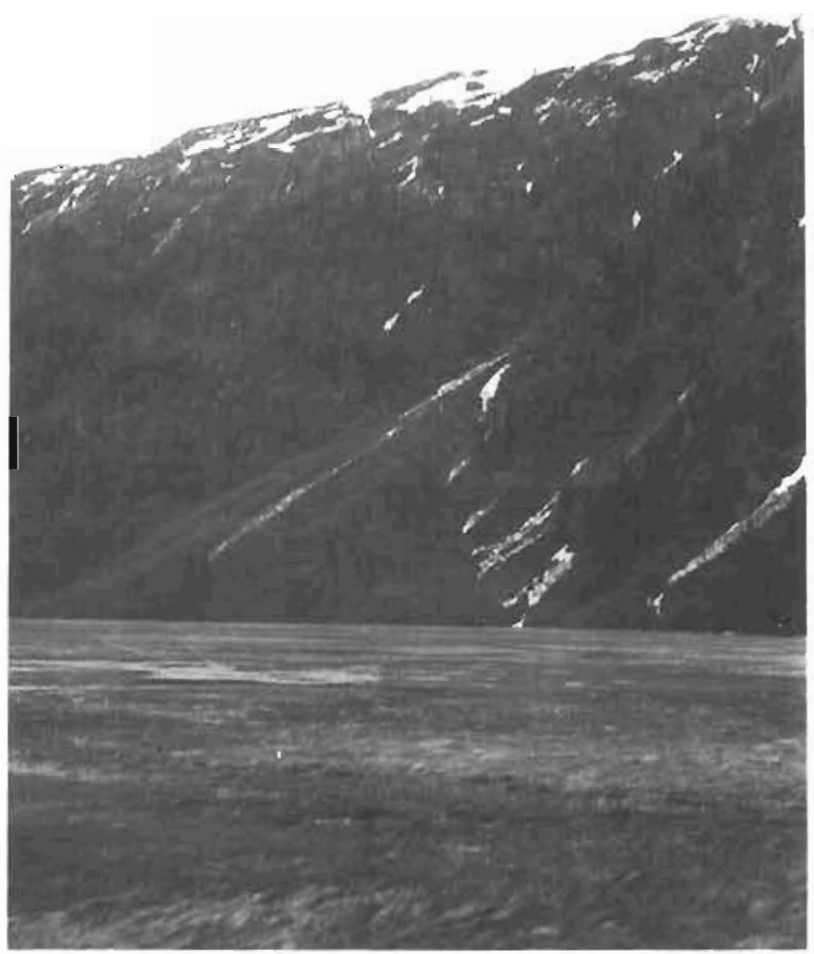

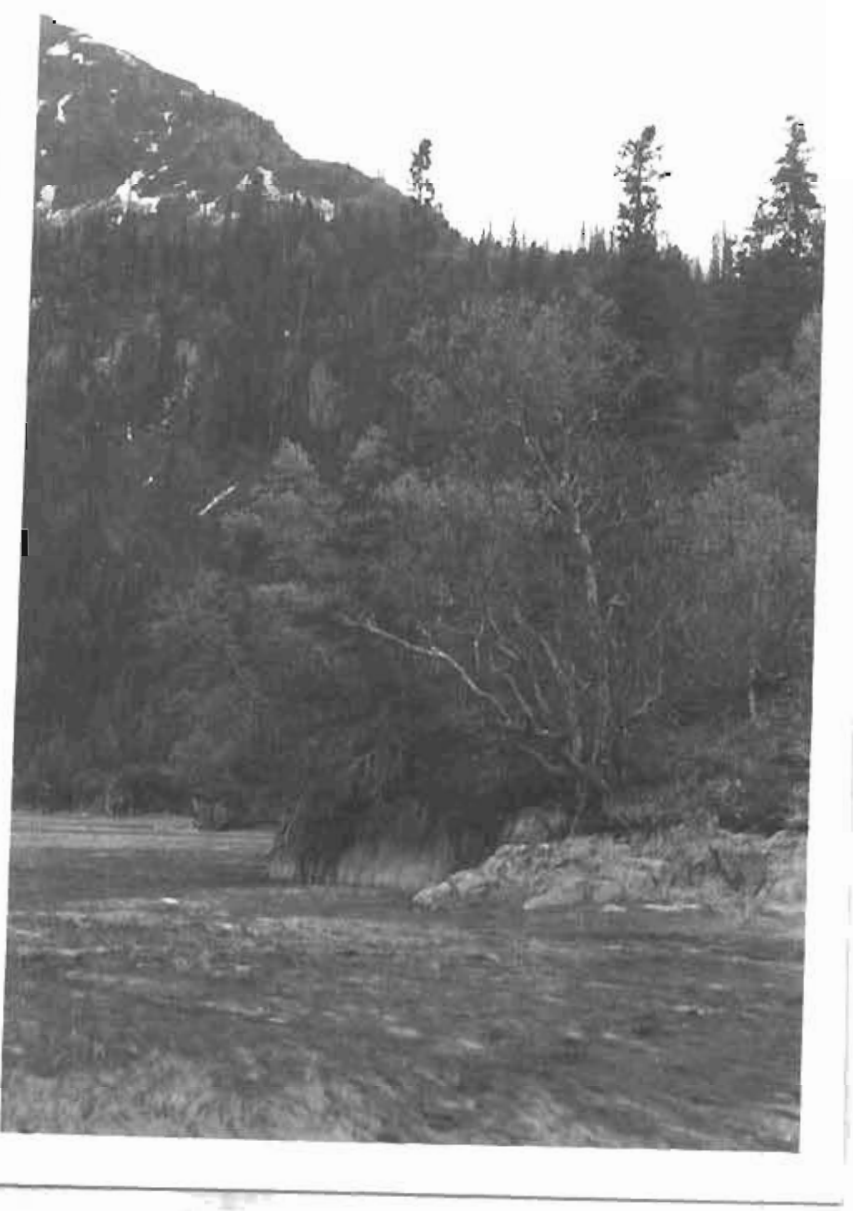

Looking southeasterly from northwest end of ridge, along north side and across tideilats. Tuxedni Bay magnetite Invegtigation.

$$
\text { May 30, } 1953
$$


Looking easterly to east end of tide-plats on north side of ridge. Plane landed in center backpround, 1紊 mile distant. Flats submerged to depth of 1 竞 to 2 feet at; extreme high tide only. Begt landing area maximum length 1000 feet.

$$
\text { May 30, } 1953
$$

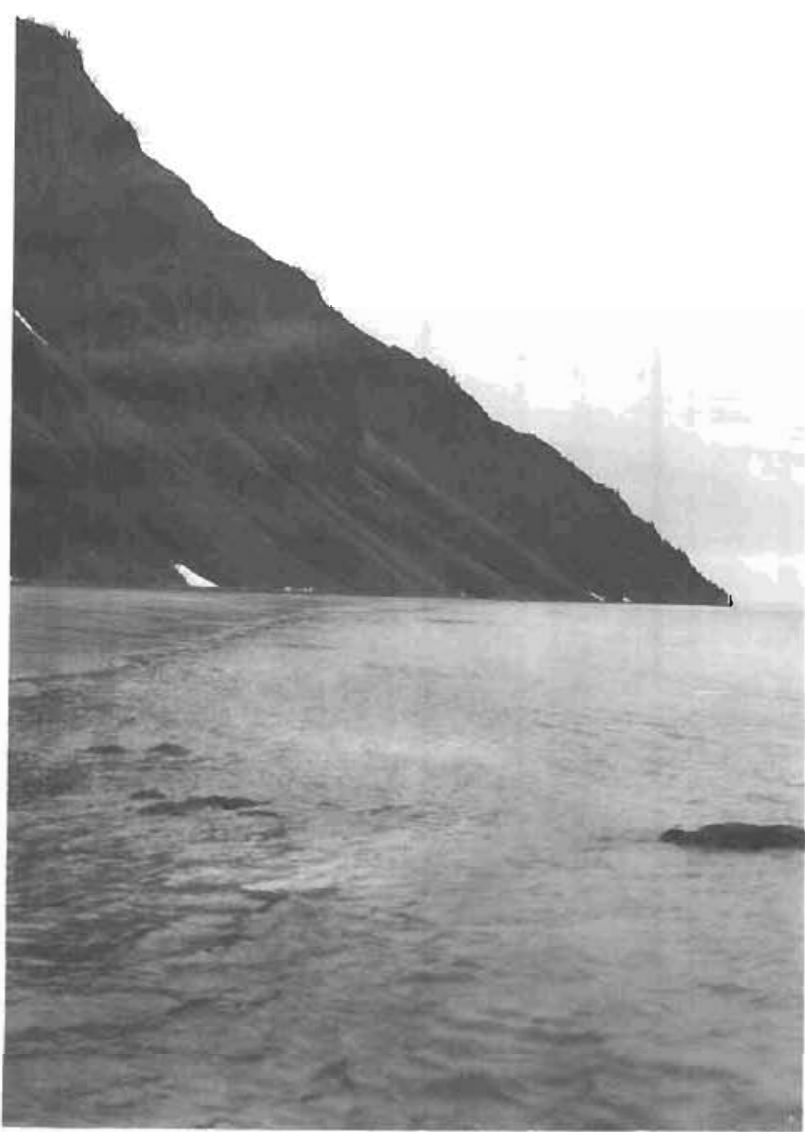

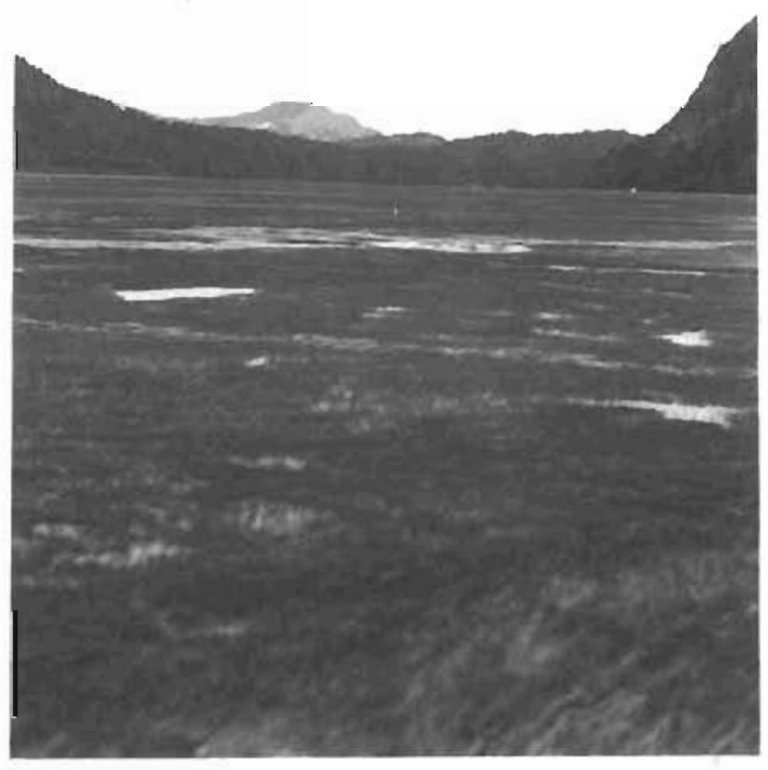

Looking easterly along south side of ridge, with section of Tuxedni. Bay in foreground. Taken from southwest point of ridge, in viclnity of reported (Plate 2, Bul, 722-D, U. S. G. S.) magneti te occurrence, which was not located. May 30,1953 


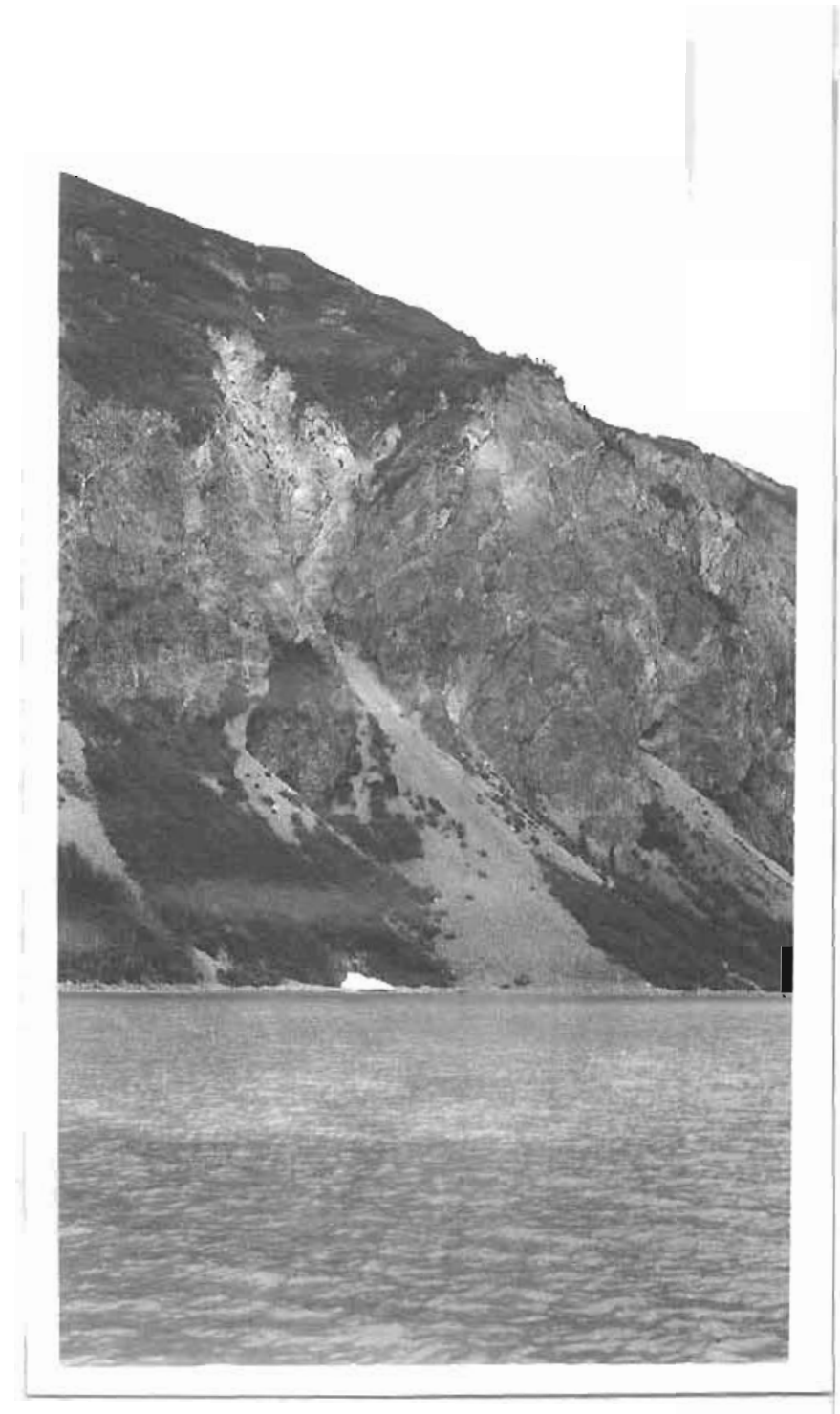

Looking northeasterly from beat showing oentral section of ridge on vorth side of Trusedint Bay. Formation exposed is comprosed entirely of varlous colored polcanics and few irregular light and derle alkes.

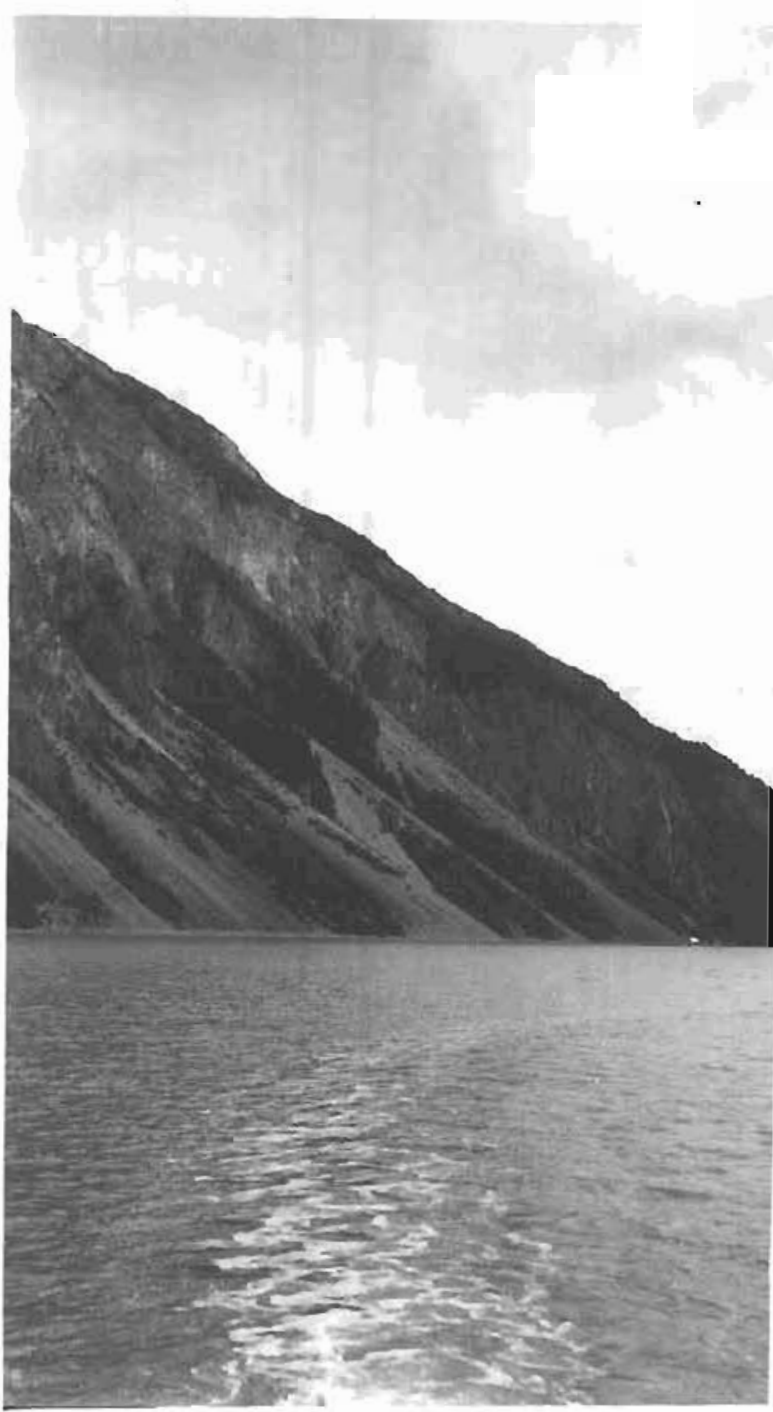

View ehowling eagtern end of ridge on north side of Tuxedni Bay. Volcanics In contact with granite at extreme right at aboreline.

Jume 12, 1953

Tuxodni Bay magnet1te Investogation of arer. Mineralization noted oonfined to disseminated pyrrhotite and pyste. Abundent iron stained areas derived from pyrrhotite oxidetion. 


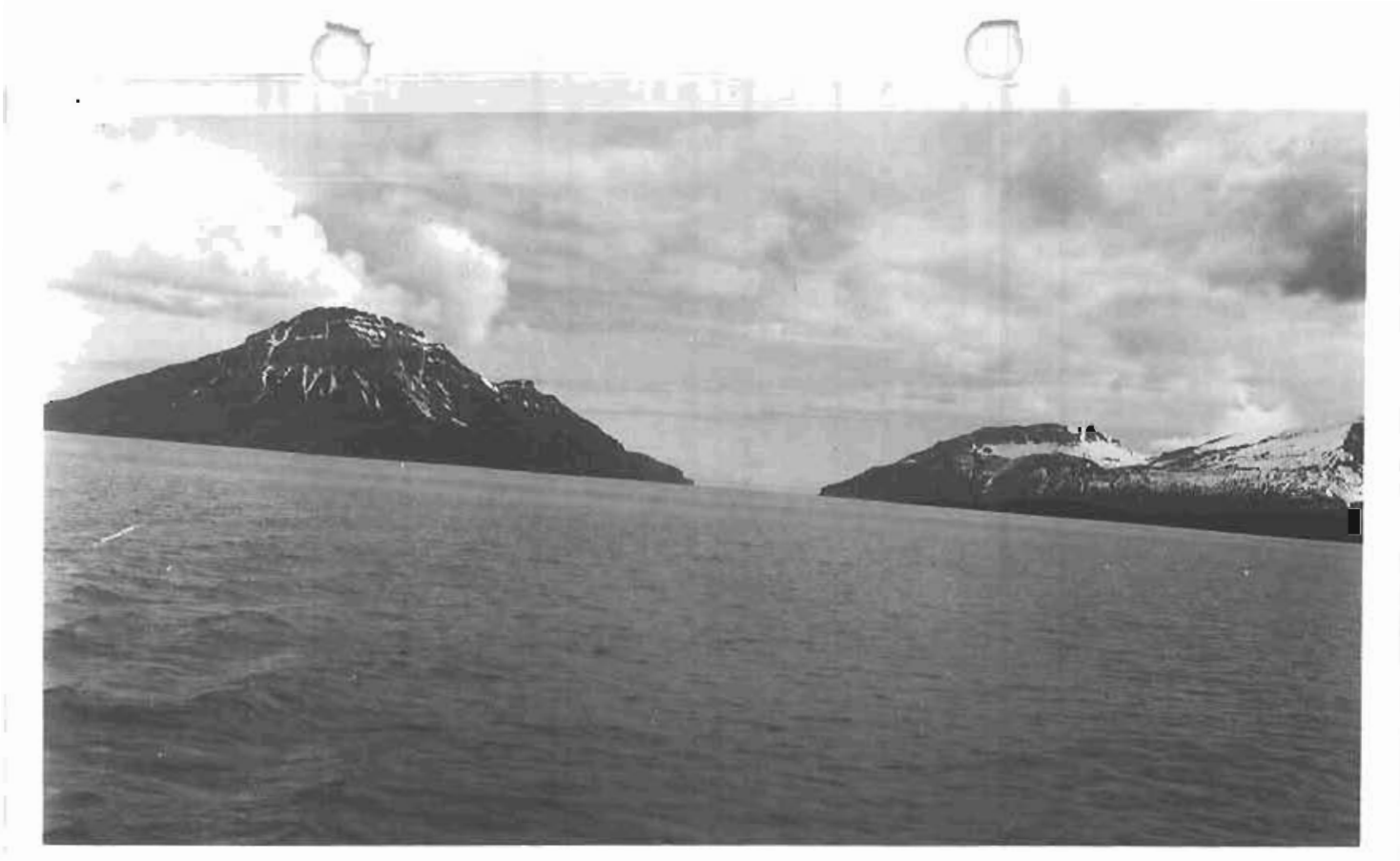

Vlews looldng southesst through Turedint Herbor from Turednl Bay Into Cook Inlet. June 12, 1953

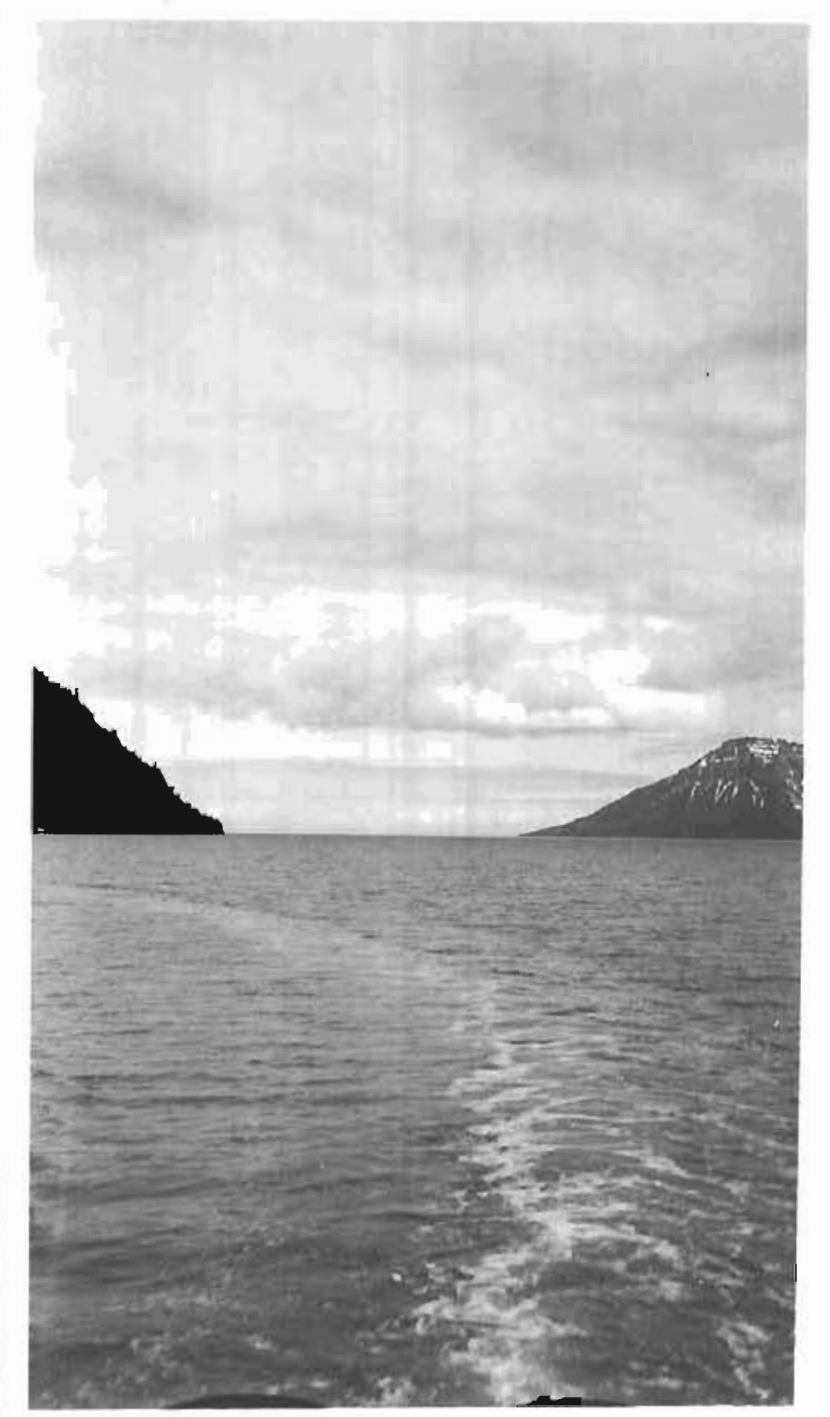




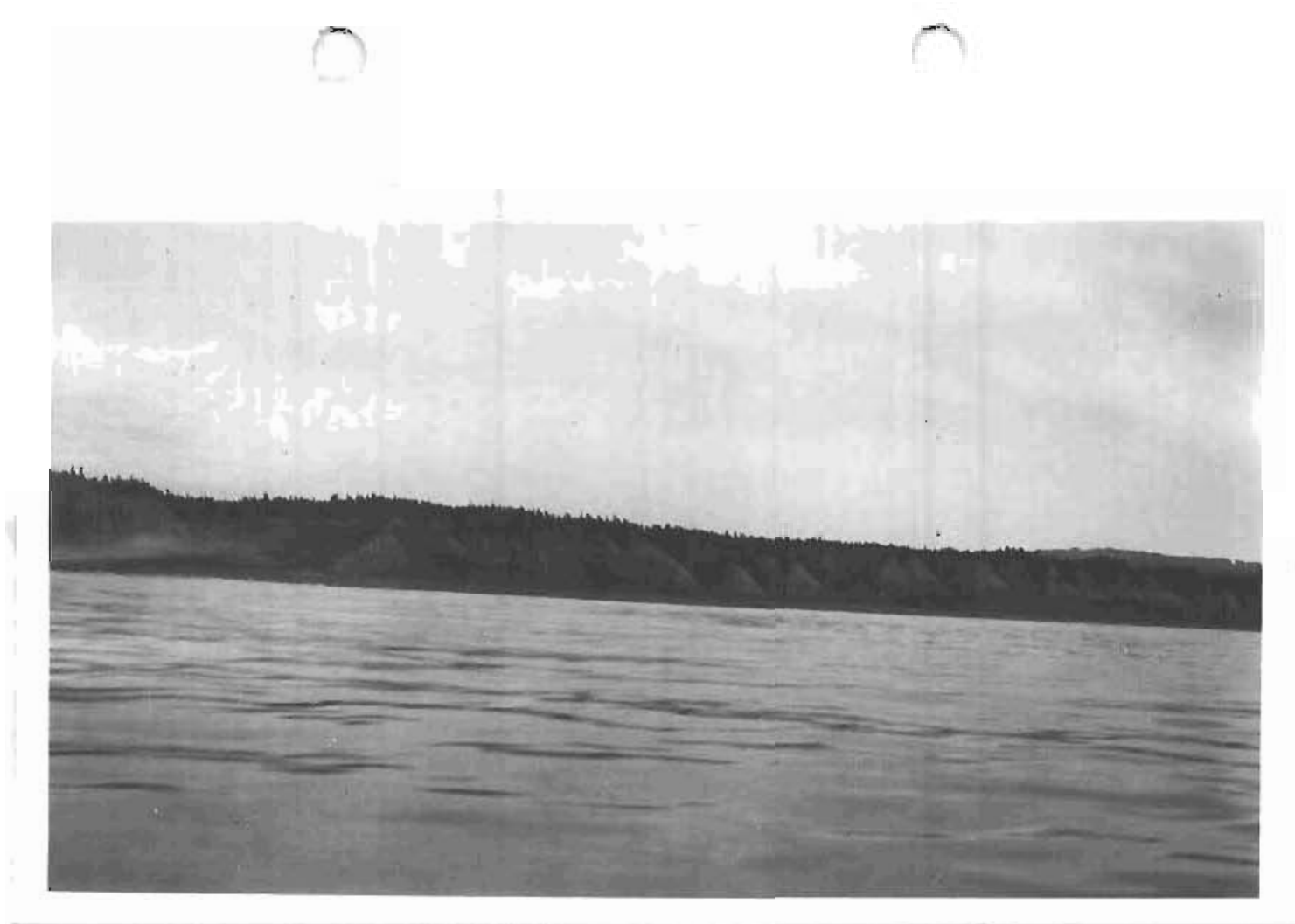

\section{Jume 13, 1953. 7830 PM. Low overoast.}

Views of east shore of Cook Inlet along whioh number of coet are platnly visible along this 6 mile seotion. Trken from point about one wile south of Fidelgo Packing Compeny flsh trap.

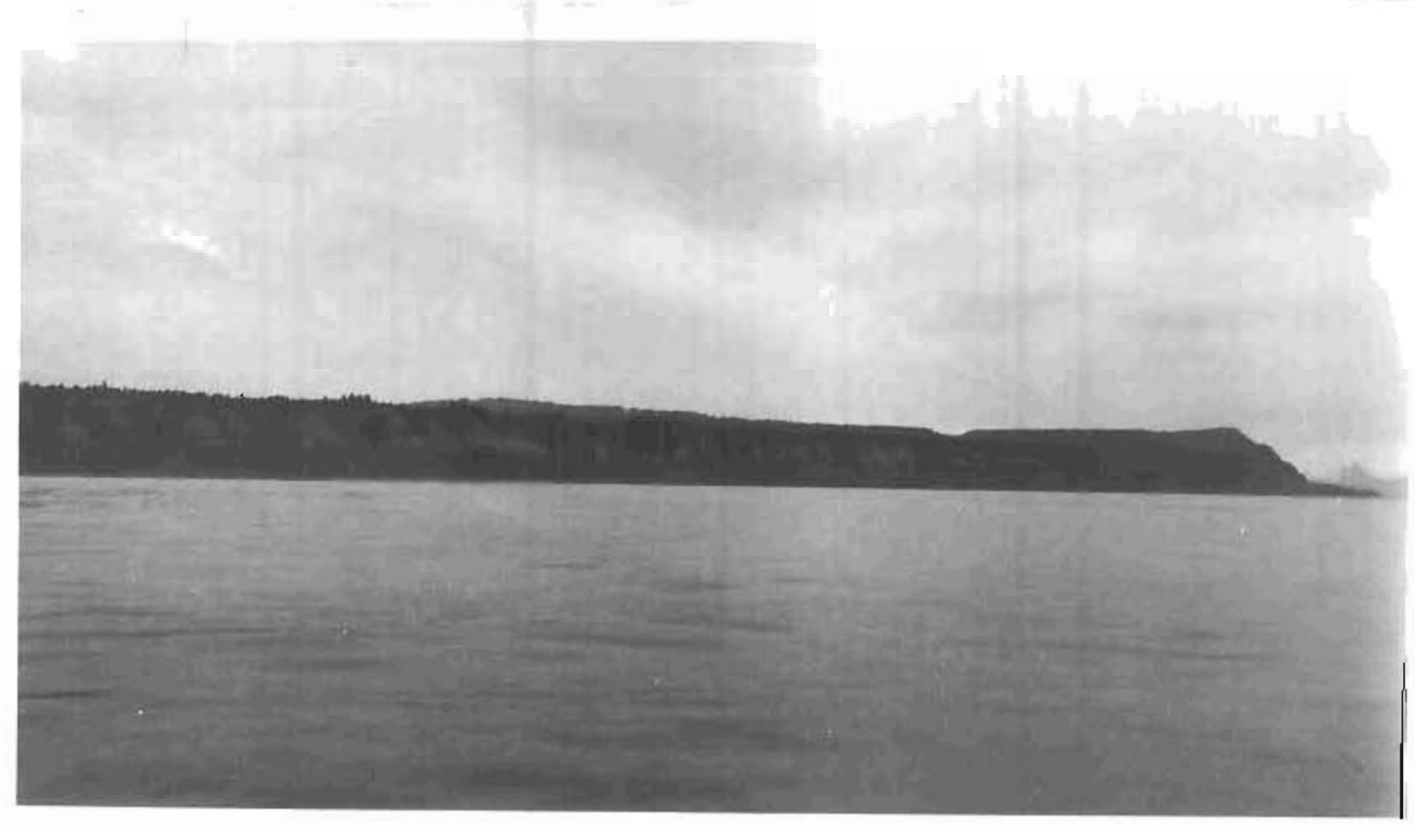




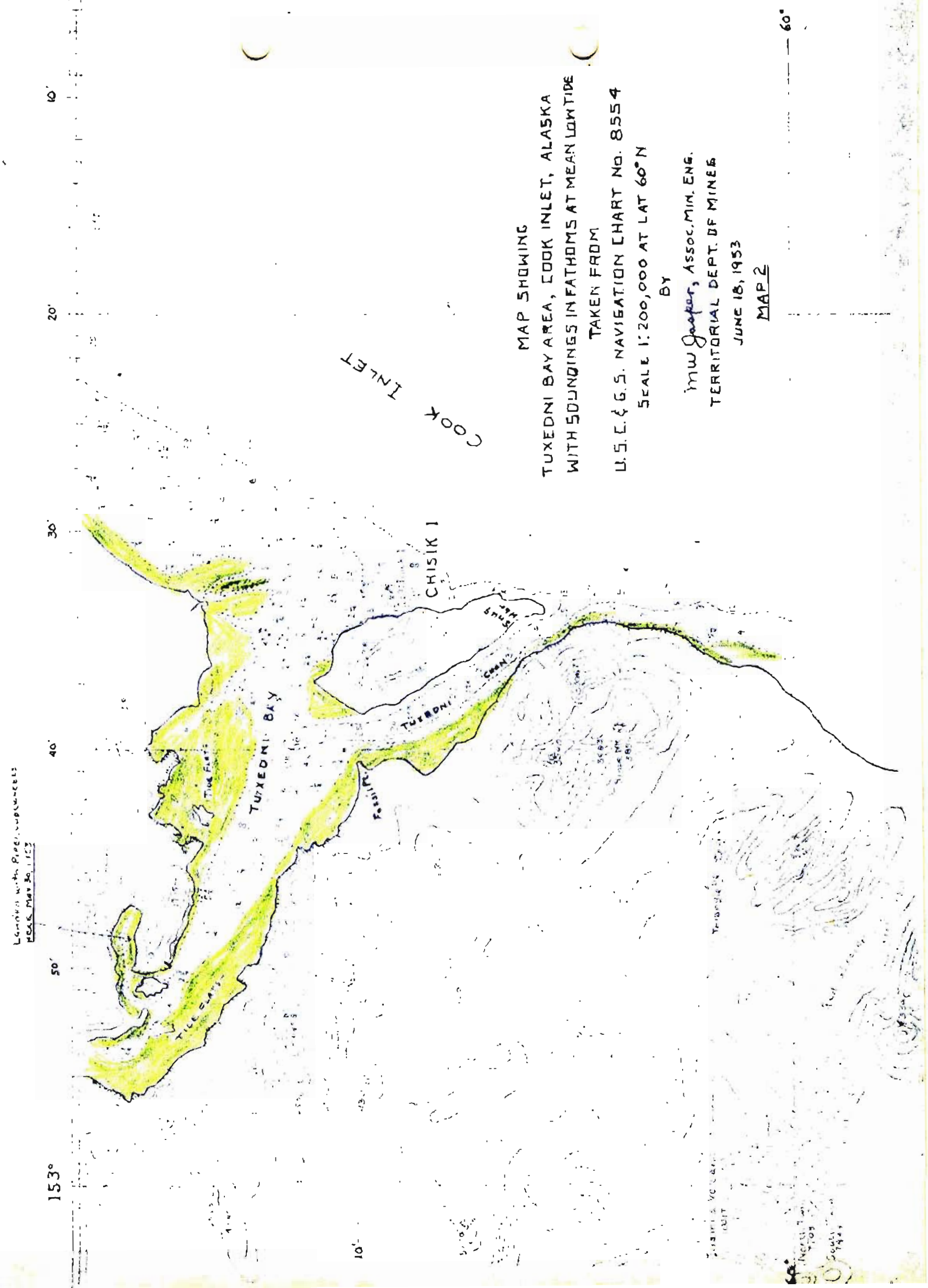




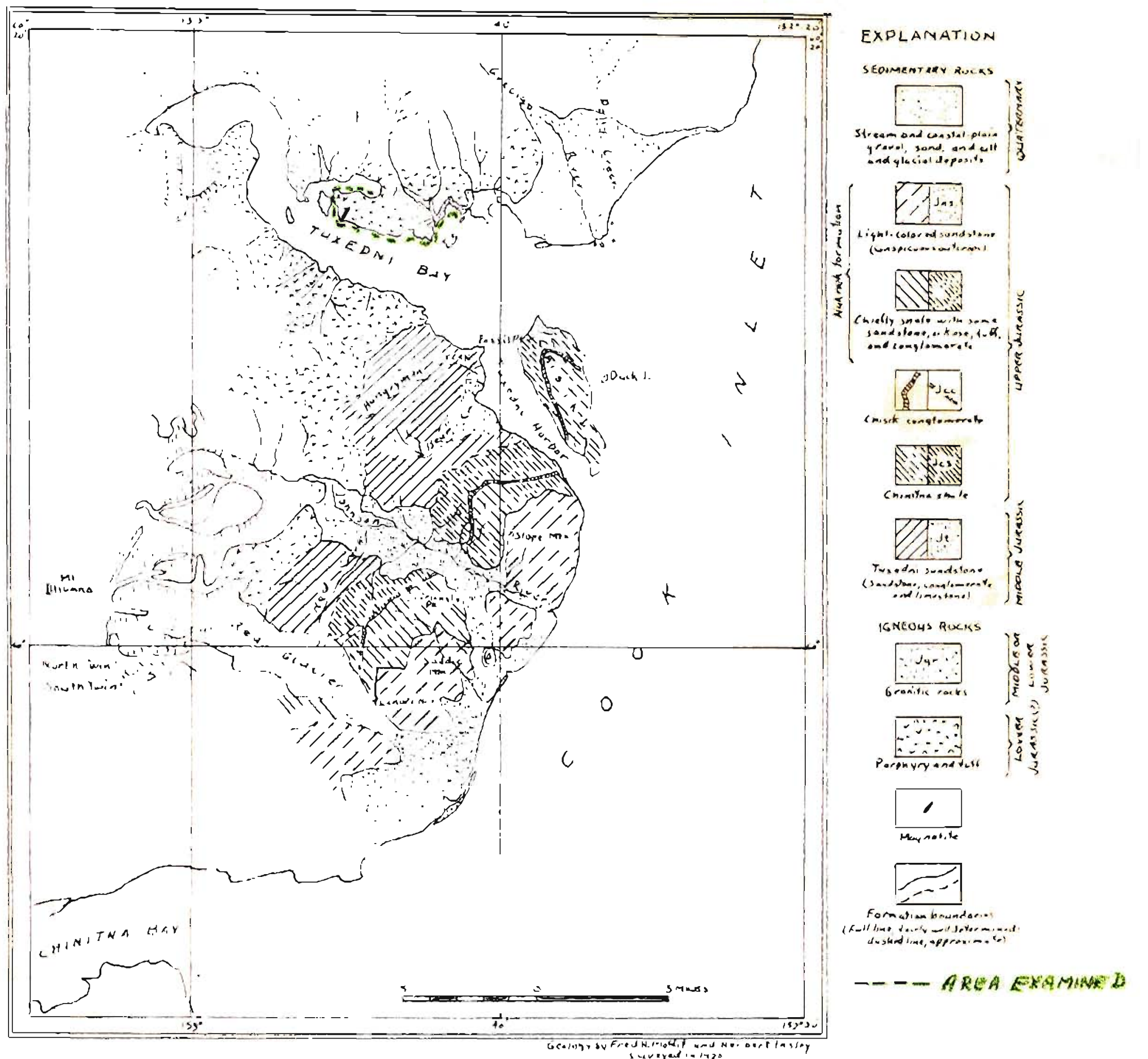

CEOLOLIC MAD OF TA EDNI AAV ANO VILANIT

REPORT OM

MAGMETITE INVISSTIGATION

IUEDDMJ BAY AREA

JURE 12,115

By-Minvaspea' disol Min. Eng

TERRITORINE UEP T. OR MIITES MAP 1 